JPBIO (Jurnal Pendidikan Biologi)

Vol. 2, No. 1, April 2017 | 1 - 8

ISSN 2540-802x (Online)

DOI: http://dx.doi.org/10.31932/ JPBIO (Jurnal Pendidikan Biologi)

http://jurnal.stkippersada.ac.id/jurnal/index.php/JBIO

\title{
PENERAPAN METODE PEMBELAJARAN PROBLEM SOLVING TERHADAP KEMAMPUAN BERPIKIR KRITIS SISWA PADA POKOK BAHASAN SISTEM PENCERNAAN MANUSIA DI KELAS VIII SEKOLAH MENENGAH PERTAMA NEGERI 1 SELIMBAU TAHUN PELAJARAN 2016/2017
}

\author{
Hardi Candra Pratama ${ }^{1}$, Florentina Rahayu Esti Wahyuni ${ }^{2 *}$, Emilia Dewiwati Pelipa ${ }^{3}$ \\ ${ }^{1}$ Mahasiswa Program Studi Pendidikan Biologi, STKIP Persada Khatulistiwa Sintang \\ ${ }^{2,3}$ Dosen Program Studi Pendidikan Biologi, STKIP Persada Khatulistiwa Sintang \\ E-mail: hardicandrapratama94@gmail.com, esti_pandi@ymail.com*, \\ pelipaemilia@gmail.com
}

Diterima: 10 Februari 2017

Direvisi: 01 Maret 2017

Disetujui: 20 Maret 2017

\begin{abstract}
ABSTRAK
Penelitian ini bertujuan untuk mengetahui pengaruh Penerapan Metode Pembelajaran Problem Solving terhadap Kemampuan Berpikir Kritis Siswa. Metode penelitian yang digunakan adalah metode kuantitatif. Bentuk penelitian adalah Quasi-eksperiment dengan desain penelitian Nonequivalent Control Group Desain. Populasi dalam penelitian ini adalah siswa kelas VIII di sekolah SMP Negeri 01 Selimbau Tahun 2016/2017 yang berjumlah 67 siswa. Sampel yang digunakan dalam penelitian ini adalah Kelas VIII B sebagai kelas eksperimen dan kelas VIII C sebagai kelas kontrol dengan menggunakan teknik pengambilan sampel Purposive Sampling. Alat pengumpulan data yang digunakan adalah lembar observasi, lembar tes dan angket. Hasil analisis data observasi guru di kelas eksperimen dengan presentasi $100 \%$, berkriteria baik, sedangkan data observasi siswa pada kelas eksperimen dengan presentasi rata-rata $100 \%$ berkriteria baik. Setelah dianalisis diketahui bahwa Metode Pembelajaran Problem Solving berpengaruh secara signifikan terhadap kemampuan berpikir kritis siswa. Hal ini ditunjukan dengan data Pretest dan Posttest kelas eksperimen dihitung menggunakan Program SPSS18.0 dengan nilai Sig. (2tailed) sebesar 0,000 dan hasil ini kurang dari $0,05 \quad(0,000<0,05)$, sehingga dapat disimpulkan bahwa $\mathrm{HO}$ ditolak dan $\mathrm{HI}$ diterima. Sehingga dapat disimpulkan bahwa terdapat pengaruh yang signifikan Metode Pembelajaran Problem Solving Terhadap Kemampuan Berpikir Kritis Siswa Pada Pokok Bahasan Sistem Pencernaan Manusia di Kelas VIII SMP Negeri 01 Selimbau Tahun Pelajaran 2016/2017. Setelah dilakukan pengolahan data angket diperoleh rata-rata nilai $100 \%$ dengan kategori sangat kuat.
\end{abstract}

Kata Kunci: problem solving, kemampuan berpikir kritis, sistem pencernaan manusia.

\section{ABSTRACT}

This research aimed to know the effect of Implementation Method Learning of Problem Solving Thinking Ability Students. The research method used is quantitative method. Research forms is Quasi- 
experiments. Research design Nonequivalent Control Group Design. Population in this research is of student class VIII Junior High School Negeri 01 Selimbau year 2016/2017 amounting 67 student. The sample used of this research is a Class VIII $B$ as an experimental class and class VIII $C$ as the control class by using a sampling technique purposive sampling technique. Devices collection of data tecnique used is the direct observations observation sheet, sheet test and indirect communication (questionnaire). Results of data analysis in experimental class teacher with the presentation of $100 \%$, berkriteria good, while the observation data students in the experiment class with presentations average of $100 \%$ with good criterion. After analysis is known that Learning Method Problem Solving significantly influence student's critical thinking Ability. This is evidenced by the data pretest and posttest experiment class is calculated using the SPSS Program 18.0 with value of Sig. (2-tailed) equal to 0.000 and the result is less of from $0.05(0.000<0.05)$, so it may be concluded that $\mathrm{HO}$ is rejected and $\mathrm{HI}$ accepted. It can be concluded that there is significant influence Learning Method Problem Solving Thinking Ability Of Students In Highlights Human The Digestive System in Class VIII Junior High School Negeri 01 Selimbau in academic year 2016/2017. After processing questionnaire data gained an average of $100 \%$ value with very a strong category.

Keywords: problem solving, critical thinking ability, human digestive system

\section{PENDAHULUAN}

Pendidikan sangat penting dalam kehidupan, oleh karena itu pendidikan tidak dapat dipisahkan dari kehidupan. Bahkan maju mundurnya suatu masyarakat atau bangsa ditentukan oleh maju dunia pendidikan. Dalam setiap proses pendidikan, peserta didik merupakan komponen yang mempunyai kedudukan yang paling sentral, dan tidak mungkin suatu proses pendidikan dapat berlangsung tanpa adanya kehadiran peserta didik. Menurut fisher (2012: 1), "Dalam beberapa tahun terakhir, "berpikir kritis" telah menjadi suatu istilah yang sangat populer dalam dunia pendidikan. Karena banyak alasan, para pendidik menjadi lebih tertarik mengajarkan "keterampilan-keterampilan berpikir" dengan pelbagai corak daripada mengajarkan informasi dan isi. Berpikir kritis adalah kemampuan dalam membuat penilaian terhadap satu atau lebih pernyataan dan membuat keputusan yang objektif bedasarkan pada pertimbangan dan fakta yang mendukung.

Problem Solving sangat cocok jika dikaitkan dengan berpikir kritis karena setiap orang yang menemukan masalah pasti mencari solusi atau jalan keluar, salah satunya menggunakan pemikiran dan juga logika untuk memecahkan masalah yang ditemukanya, begitu juga jika terjadi pada dunia pendidikan dalam proses belajar mengajar. Guru harus bijaksana dalam menentukan suatu metode yang sesuai yang dapat menciptakan situasi dan kondisi kelas yang kondusif agar proses belajar mengajar dapat berlangsung sesuai dengan tujuan yang diharapkan. Seorang guru harus memperhatikan proses dan hasil kegiatan belajar dalam meningkatkan mutu pendidikan. Kegiatan belajar merupakan keadaan dimana terdapat aktivitas guru dan peserta didik,serta interaksinya dalam proses pembelajaran untuk mencapai tujuan pembelajaran tertentu.

Bedasarkan observasi yang telah dilakukan dan juga informasi yang diperoleh di SMP Negeri 1 Selimbau, kemampuan berpikir kritis peserta didik kelas VIII SMP Negeri 1 Selimbau kurang, terlihat bahwa peserta didik lebih banyak diam dan hanya mendengarkan pembelajaran, tidak aktif dalam proses pembelajaran, rasa ingin tahu mereka kurang tentang materi yang dipelajari, hal ini dikarenakan model pembelajaran yang digunakan masih bersifat konvensional, dimana proses pembelajaran berpusat pada guru dan peran peserta didik hanya sebagai pendengar dan penulis.

Pembahasan materi sistem pencernaan pada manusia merupakan materi yang sangat mendasar dan terkait materi-materi IPA lainnya yang akan dipelajari oleh peserta didik pada jenjang yang lebih tinggi. Selain itu, materi sistem pencernaan manusia penting untuk diperhatikan agar kita mengerti dan memahami arti pentingnya menjaga kesehatan. Perlu diterapkan satu metode pembelajaran yang dimungkinkan dapat meningkatkan kualitas belajar dalam mengembangkan kemampuan berpikir kritis peserta didik diperlukan metode pembelajaran yang tepat untuk mencapai kemampuan berpikir kritis peserta didik, yaitu menggunakan problem solving (belajar memecahkan masalah). 
Mengatasi masalah tersebut, peneliti tertarik untuk melakukan ujicoba dengan menggunakan metode Problem Solving, sehingga peneliti mengangkat karya tulis ini dengan judul "Penerapan Metode Pembelajaran Problem Solving Terhadap Kemampuan Berpikir Kritis Siswa Pada Pokok Bahasan Sistem Pencernaan Manusia di Kelas VIII Sekolah Menengah Pertama Negeri 1 Selimbau Tahun Pelajaran 2016/2017".

\section{METODE PENELITIAN}

Pendekatan metode penelitian dalam skripsi ini adalah denganpendekatan kuantitatif. $\mathrm{Hal}$ ini sesuai dengan pendapat Arikunto (2006: 12) yang mengemukakan penelitian kuantitatif adalah pendekatan penelitian yang banyak dituntut menggunakan angka, mulai dari pengumpulan data, penafsiran terhadap data tersebut, serta penampilan hasilnya.Bentuk penelitian yang digunakan dalam penelitian ini adalah Eksperimen,Menurut Sukardi (2013: 16), "Penelitian eksperimen merupakan penelitian inti dari penelitian yang ada. Karena dalam penelitian eksperimen para peneliti melakukan tiga persyaratan dari suatu bentuk penelitian, yaitu kegiatan mengontrol, memanipulasi dan observasi". Peneliti menggunakan rancangan Quasi experiment (eksperimen semu). Desain penelitian yang digunakan adalah Non-Equivalent Control Group Desain. Pengambilan sampel dilakukan dengan teknikpurposivesampling.

Penelitian ini dilaksanakan di SMA Negeri1 Selimbau semester ganjil 2016/2017.Populasi penelitian ini adalah seluruh siswa kelas VIIIA, VIIIB dan VIIIC ,dengan jumlah siswa kelas VIIIA sebanyak 23 siswa, kelas VIIIB sebanyak 22 siswa dan VIIIC sebanyak 22 siswa. Kelas VIIIB sebagai kelas eksperimen sedangkan kelas VIIIC sebagai kelas kontrol.Variabel bebas yaitu metode pembelajaran Problem Solving, dan variabel terikat yaitu berpikir kritis. Pelaksanaan pembelajaran dilaksanakan masing-masing 2 kali pertemuan pada pokok bahasan Sistem Pencernaan Manusia.

Instrumen yang digunakan dalam penelitian ini adalah teknik komunikasi langsung yaitu pengumpulan data yang diperoleh melalaui lembar obeservasi untuk memperoleh informasi kegiatan pembelajaran guru dan siswa apakah sesuai dengan langkah-langkah pembelajaran Problem Solving pada pokok bahasan sistem pencernaan manusia. Teknik pengukuran yaitu pengumpulan data yang diperoleh melalui soal tes bertujuan untuk memperoleh hasil kemampuan berpikir kritis siswa. Teknik observasi tak langsung yaitu pengumpulan data yang diperoleh melalui angket bertujuan untuk mendapatkan tanggapan siswa tentang metode pembelajaran Problem Solving.

Teknik analisis data hasil observasi dan angket menggunakan perhitungan persentase dan analisis pada soal tes meliputi (a) uji normalitas, (b) uji homogenitas, (c) uji hipotesis dengan uji t (uji signifikan) yang berfungsi apabila peneliti ingin mencari pengaruh penerapan metode pembelajaran Problem Solving terhadap kemampuan berpikir kritis siwa pada pokok bahasan sistem pencernaan manusia.

\section{HASIL PENELITIAN}

Observasi siswa dikelas eksperimen dilakukan dimulai dari pembukaan pembelajaran sampai penutup pembelajaran. Proses pengamatan terhadap aktivitas siswa dalam proses pembelajaran peneliti dibantu satu observer. Nilai hasil observasi siswa pada pertemuan pertama $100 \%$ dan pertemuan kedua $100 \%$, adapun nilai rata-rata dari pertemuan pertama dan kedua tersebut adalah $100 \%$. Bedasarkan hasil rata-rata akumulasi pertemuan pertama dan kedua menunjukan kreteria baik yang artinya siswa melaksanakan pembelajaran dengan sungguh-sungguh.

Hasil tes kemampuan berpikir kritis siswa pada penelitian ini dilihat dari pretest dan posttest siswa pada materi sistem pencernaan manusia sesuai dengan metode pembelajaran yaitu Problem Solving. Penilaian hasil kemampuan berpikir kritis siswa dilakukan pada kelas eksperimen dan kelas kontrol yang bertujuan untuk membedakan hasil belajar menggunakan metode pembelajaran Problem Solving dan pembelajaran konvensional.Adapun rekapitulasi hasil kemampuan berpikir kritis siswa dapat dilihat pada Tabel 1. Pada Tabel 1. Menunjukkan hasil dari pretest dan posttest kelas eksperimen dan kontrol, terlihat bahwa nilai pretest kelas eksperimen dengan jumlah siswa 22 diperoleh nilai 
tertinggi 64 , nilai terendah 26 dan nilai rata-rata 44,13 sedangkan pada posttest diperoleh nilai tertinggi 98, nilai terendah 60 dan nilai rata-rata 78,13. Pada pretest kelas kontrol dengan jumlah siswa 22 diperoleh nilai tertinggi 78, nilai terendah 39 dan nilai rata-rata 49,86 sedangkan pada posttest nilai tertinggi 81 , nilai terendah 41 dan nilai rata-rata 58,09.

Tabel1 Hasil Kemampuan Berpikir Kritis Siswa

\begin{tabular}{lllll}
\hline \multirow{2}{*}{ Nilai } & \multicolumn{2}{l}{ Kelas Eksperimen } & \multicolumn{2}{l}{ Kelas Kontrol } \\
\cline { 2 - 5 } & Pretest & Posttest & Pretest & Posttest \\
\hline N & 22 & 22 & 22 & 22 \\
Nilai Tertinggi & 64 & 98 & 78 & 81 \\
Nilai Terendah & 26 & 60 & 39 & 41 \\
Nilai Rata-Rata & 44,13 & 78,13 & 49,86 & 58,09 \\
\hline
\end{tabular}

Data yang digunakan dalam perhitungan Indeks Gain Hake adalah nilai pretest dan posttest kelas kontrol dan kelas eksperimen. Rekapitulasi hasil analisis indeks gain hake dapat dilihat pada Tabel 2.

Tabel 2 Hasil Analisis Indeks Gain Hake

\begin{tabular}{lll}
\hline Kelas & Indeks Gain Hake & Kategori \\
\hline Eksperimen & 0,60 & Sedang \\
Kontrol & 0,16 & Sangat Rendah \\
\hline
\end{tabular}

Pada Tabel 2 menunjukan Analisis Indeks Gain Hake antara kelas eksperimen dan kontrol, kelas eksperimen dengan nilai 0,60 dengan katagori sedang dan kelas kontrol dengan nilai 0,16 dengan katagori sangat rendah. Uji normalitas dalam penelitian ini menggunakan metode Chi Kuadrat dengan bantuan komputer program SPSS StatisticS 18.0. Hasil uji normalitas data dapat dilihat dalam Tabel 3.

Tabel 3 Hasil Uji Normalitas Data Kelas Eksperimen dan Kelas Kontrol

\begin{tabular}{llrllll}
\hline Kelas & Jenis Tes & $\bar{x}$ & S & Sig. & a & Kesimpulan \\
\hline \multirow{2}{*}{ Kelas eksperimen } & Pretest & 44,13 & 11,81 & 0,774 & 0,05 & Normal \\
& Posttest & 78,13 & 12,89 & 0,786 & 0,05 & Normal \\
\multirow{2}{*}{ Kelas kontrol } & Pretest & 49,86 & 9,43 & 0,825 & 0,05 & Normal \\
& Posttest & 58,09 & 10,28 & 0,896 & 0,05 & Normal \\
\hline
\end{tabular}

Pada Tabel 3 menunjukkan uji normalitas data kelas eksperimen dan kontrol yang hasilnya berdistribusi normal. Pengujian homogenitas data pretest dan postets antara kelas eksperimen dan kelas kontrol dianalisis dengan Independent Samples Test menggunakan program SPSSstatistics 18.0. Hasil uji homogenitas pretest dan posttest kelas eksperimen dan kelas kontrol dapat dilihat pada Tabel 4.

Tabel 4 Hasil Uji Homogenitas Pretest dan Posttest Kelas Eksperimen dan Kelas Kontrol

\begin{tabular}{|c|c|c|c|c|c|}
\hline Jenis Tes & & a & Sig. & Ket. & Kes. \\
\hline $\begin{array}{l}\text { Pretest } \\
\text { kelaseksperimen } \\
\text { kelas kontrol }\end{array}$ & dan & $\begin{array}{l}0,0 \\
5\end{array}$ & 0,284 & $0,284>0,05$ & Homogen \\
\hline $\begin{array}{l}\text { Posttest } \\
\text { kelaseksperimen } \\
\text { kelas kontrol }\end{array}$ & dan & $\begin{array}{l}0,0 \\
5\end{array}$ & 0,144 & $0,144>0,05$ & Homogen \\
\hline
\end{tabular}


Pada Tabel 4 menunjukkan uji homogenitas data kelas eksperimen dan kontrol yang hasilnya berdistribusi homogen. Pada Tabel 5 menunjukkan uji hipotesis data kelas eksperimen dan kontrol bedasarkan rumusan masalah yang sudah ada.

Tabel 5 Uji Hipotesis

\begin{tabular}{llll}
\hline Jenis Tes & Sig. (2-tailed) & a & Kesimpulan \\
\hline $\begin{array}{l}\text { Pretest kelas eksperimen dan kelas } \\
\text { kontrol }\end{array}$ & 0,083 & 0,05 & H0 diterima \\
$\begin{array}{l}\text { Posttest kelas eksperimen dan } \\
\text { kelas control }\end{array}$ & 0,000 & 0,05 & HIditerima \\
$\begin{array}{l}\text { Pretest dan posttest } \\
\text { kelaseksperimen }\end{array}$ & 0,000 & 0,05 & HIDiterima \\
$\begin{array}{l}\text { Pretest dan posttest kelas control } \\
\text { Pre,008 }\end{array}$ & 0,05 & HIDiterima \\
\hline
\end{tabular}

\section{PEMBAHASAN}

\section{Deskripsi aktivitas guru dan siswa di kelas eksperimen}

Observasi guru dilakukan saat berlangsungnya penerapan metode pembelajaran Problem Solving. kegiatan observasi ini melibatkan satu orang observer, sedangkan peneliti berperan sebagai pelaksana dalam menerapkan metode pembelajaran Problem Solving. bedasarkan analisis observasi guru pada pertemuan pertama dan kedua, didapat rata-rata presentasi pelaksanaan $100 \%$ dengan kriteria "Sangat Baik", artinya guru telah melaksanakan pembelajaran mulai dari pendahuluan sampai penutup pembelajaran dengan baik yaitu sesuai dengan rangkaian kegiatan pembelajaran yang terdapat pada langkahlangkah penerapan metode pembelajaran Problem Solving.

Bedasarkan hasil observasi siswa pada pertemuan pertama dan kedua di kelas eksperimen yang diamati oleh satu orang observer dengan jumlah siswa 22 orang, terlihat bahwa siswa telah mengikuti dan melaksanakan metode pembelajaran Problem Solving dengan sangat baik. Hasil observasi siswa pada pertemuan pertama dan kedua yang dilakukan oleh observer yang berjumlah satu orang untuk 22 siswa didapat rata-ratanya $100 \%$ dengan demikian hasil pengamatan berada pada rentang $80 \%-100 \%$ yeng berkriteria "Sangat Baik". Artinya, dari pertemuan pertama dan kedua siswa telah mengikuti pembelajaran mulai dari pendahuluan sampai penutup dengan baik. Persentase keterlaksanaan pembelajaran oleh siswa ini menunjukan bahwa guru dan siswa sama-sama antusias dalam proses belajar mengajar menggunakan metode pembelajaran Problem Solving. Hal ini didukung oleh hasil penelitian sebelumnya, yaitu Ressati (2014) dengan judul penelitian "Efektivitas Metode Pembelajaran Problem Solving Terhadap Kemampuan Berpikir Kritis Siswa Pada Sub Materi Organ dan Sistem Organ di Kelas XI" yang menyatakan bahwa siswa melaksanakan pembelajaran sesuai dengan langkah-langkah yang terdapat pada Problem Solving, dan siswa belajar dengan baik dan konsentrasi terhadap masalah yang harus dipecahkan atau dicari penyelesaiannya. Hasil observasi siswa yang telah dikumpulkan oleh kedua observer pada kelas eksperimen. Jadi, persentasi total kedua observer yaitu $94,74 \%$, dapat disimpulkan bahwa proses pembelajaran dengan menggunakan metode pembelajaran Problem Solving berlangsung sangat baik.

\section{Perbedaan kemampuan berpikir kritis siswa pada pretest antara siswa kelas eksperimen dan siswa kelas kontrol}

Dalam penelitian ini, analisis data menggunakan SPSS statistic 18 bedasarkan hasil nilai tertinggi kelas eksperimen sebesar 64 dengan nilai terendah 26 dan rata-rata nilai siswa sebesar 44,13. Sedangkan pada kelas kontrol diperoleh nilai tertinggi 78 dengan nilai terendah 39 dan rata-rata nilai siswa sebesar 49,86. Setelah didapat data pretest kelas eksperimen dan kelas kontrol maka uji hipotesis, hasil uji hipotesis berdasarkan hasil analisis diperoleh Sig. (2-tailed) > 0,05 yakni 0,083>0,05 dan dinyatakan tidak terdapat perbedaan. 
Pratama, dkk | Penerapan metode pembelajaran problem solving...

Pengujian hipotesis tersebut membuktikan bahwa HO diterima yakni, tidak terdapat perbedaan antara nilai rata-rata pretest kelas eksperimen dan kelas kontrol sehingga kedua sampel dikatakan memiliki kemampuan awal yang sepadan dan dapat dilanjutkan penelitian.

\section{Perbedaan kemampuan berpikir kritis siswa pada posttest antara siswa kelas eksperimen dan siswa kelas kontrol}

Dalam penelitian ini, analisis data menggunakan SPSS statistic 18 bedasarkan hasil analisisdiperoleh bahwa hasil kemampuan berpikir kritis siswa kelas eksperimen pada posttest diperoleh dengan nilai tertinggi 98 dan nilai terendah 60 sedangkan pada siswa kelas kontrol diperoleh dengan nilai tertinggi 81 dan nilai terendah 41. Sementara itu, setelah dirata-ratakan diperoleh rata-rata nilai kelas eksperimen adalah 78,13 dan rata-rata kelas kontrol adalah 58,09. Hal ini berarti rata-rata nilai posttest kelas eksperimen lebih tinggi dari kelas kontrol. Hal ini dikarenakan pada kelas kontrol proses pembelajarannya hanya menggunakan metode ceramah, sementara di kelas eksperimen menggunakan metode pembelajaran Problem Solving yang lebih banyak menuntut siswa untuk aktif dalam proses pembelajaran sehingga banyak siswa yang memahami materi yang disampaikan. Berdasarkan hasil analisis diperoleh Sig. (2-tailed) $<0,05$ yakni $0,000<0,05$ dan dinyatakan berbeda signifikan. Pengujian hipotesis tersebut membuktikan bahwa $\mathrm{HO}$ ditolak dan $\mathrm{H} 1$ diterima yakni, terdapat perbedaan yang signifikan penerapan metode pembelajaran Problem Solving terhadap kemampuan berpikir kritis siswa pada pokok bahasan sistem pencernaan manusia.

\section{Perbedaan kemampuan berpikir kritis siswapretest dan posttest pada siswa kelas eksperimen}

Bedasarkan hasil analisis kemampuan berpikir kritis siswa kelas eksperimen pretest dan posttest diketahui bahwa perolehan nilai tertinggi siswa kelas eksperimen pada pretest sebesar 64 dengan nilai terendah 26 dan rata-rata nilai siswa sebesar 44,13. Sedangkan nilai tertinggi siswa kelas eksperimen pada posttest sebesar 98 dengan nilai terendah 60 dan rata-rata nilai siswa sebesar 78,13 . Perbedaan hasil belajar siswa kelas eksperimen antara pretest dan posttest dapat dilihat melalui uji hipotesis.

Berdasarkan hasil analisis diperoleh Sig. (2-tailed) $<0,05$ yakni 0,000<0,05 dan dinyatakan berbeda signifikan. Jadi dapat dinyatakan bahwa terdapat perbedaan yang signifikan antara hasil pretest dan hasil posttest pada siswa kelas eksperimen yaitu siswa yang mendapatkan perlakuan metode pembelajaran Problem Solving. Metode problem solving pembelajaran yang menuntut siswa untuk memecahkan masalah, setelah masalah diberikan siswa dituntut untuk memecahkannya sebelum memecahkan suatu permasalahan siswa harus menyadari masalah, seperti apa masalah yang mereka ingin pecahkan kemudian merumuskan masalah setelah merumuskan masalah merumuskan hipotesis atau dugaan semetara yang mereka dapatkan setelah itu siswa harus mengumpulkan data yang singkron sesuai dengan permasalahan yang mereka hadapi setelah data terkumpul tugas siswa harus menguji hipotesis dan menentukan pilihan penyelesaiannya. Jadi dapat disimpilkan bahwa metode pembelajaran problem solving dapat meningkatkan kemampuan berpikir kritis siswa.

\section{Perbedaan kemampuan berpikir kritis siswa pretest dan posttest pada siswa kelas kontrol}

Bedasarkan hasil analisis kemampuan berpikir kritis siswa kelas kontrol pretest dan posttest diketahui bahwa perolehan nilai tertinggi siswa kelas kontrol pada pretest sebesar 78 dengan nilai terendah 39 dan rata-rata nilai siswa sebesar 49,86. Sedangkan nilai tertinggi siswa kelas kontrol pada posttest sebesar 81 dengan nilai terendah 41 dan rata-rata nilai siswa sebesar 58,09. Perbedaan hasil belajar siswa kelas kontrol antara pretest dan posttest dapat dilihat melalui uji hipotesis. 
Berdasarkan hasil analisis diperoleh Sig. (2-tailed) $<0,05$ yakni 0,008<0,05 dan dinyatakan berbeda signifikan. Jadi dapat disimpulkan bahwa terdapat perbedaan yang signifikan antara hasil pretest dan hasil posttest pada siswa kelas kontrol yaitu kelas yang tidak mendapatkan perlakuan metode pembelajaran Problem Solving.

\section{SIMPULAN}

Bedasarkan dari hasil penelitian yang telah dilaksanakan, dapat disimpulkan bahwa "Terdapat Perbedaan yang signifikan Kemampuan Berpikir Kritis Siswa Pada Pokok Bahasan Sistem Pencernaan Manusia antara kelas eksperimen maupun kelas kontrol di Kelas VIII Sekolah Menengah Pertama Negeri 1 Selimbau Tahun Pelajaran 2016/2017." (HI diterima). Bedasarkan rumusan masalah penelitian, maka dapat disimpulkan, Proses pembelajaran menggunakan metode pembelajaran Problem Solving dikelas VIII B Sekolah Menengah Pertama Negeri 01 Selimbau sebagai kelas eksperimen berjalan dengan baik. Rata-rata persentase aktivitas guru pertemuan pertama dan kedua sebesar $100 \%$. Rata-rata peresntase aktivitas siswa kelas eksperimen sebesar 100\% berkriteria "Baik".

Tidak terdapat perbedaan yang signifikan kemampuan berpikir kritis siswa hasil pretest pada kelas eksperimen dan kontrol pada materi sistem pencernaan manusia di kelas VIII Sekolah Menengah Pertama Negeri 01 Selimbau. Hal ini terlihar dari hasil rata-rata Pretest kelas eksperimen sebesar 44,13 dan rata-rata kelas kontrol sebesar 49,86. Hasil analisis juga diperoleh Sig. (2-tailed) $>0,05$ yakni 0,083>0,05 yang artinya tidak terdapat perbedaan yang signifikan.

Terdapat perbedaan yang signifikan kemampuan berpikir kritis siswa hasil posttest pada kelas eksperimen dan kontrol pada materi sistem pencernaan manusia di kelas VIII Sekolah Menengah Pertama Negeri 01 Selimbau. Hal ini terlihat dari hasil rata-rata posttest kelas eksperimen sebesar 78,13 dan rata-rata kelas kontrol sebesar 58,09. Hasil analisis diperoleh Sig. (2-tailed) $<0,05$ yakni $0,000<0,05$ yang artinya terdapat perbedaan yang signifikan.

Terdapat perbedaan yang signifikan kemampuan berpikir kritis siswa pada pretest dan posttest kelas eksperimen pada materi sistem pencernaan manusia di kelas VIII B Sekolah Menengah Pertama Negeri 01 Selimbau. Hal ini terlihat dari hasil rata-rata pretest kelas eksperimen sebesar 44,13 dan rata-rata posttest kelas eksperimen sebesar 78,13. Hasil analisis diperoleh Sig. (2-tailed) $<0,05$ yakni 0,000<0,05 yang artinya terdapat perbedaan yang signifikan.

Terdapat perbedaan yang signifikan kemampuan berpikir kritis siswa pada pretest dan posttest kelas kontrol pada materi sistem pencernaan manusia di kelas VIII C Sekolah Menengah Pertama Negeri 01 Selimbau. Hal ini terlihat dari hasil rata-rata pretest kelas kontrol sebesar 49,86dan rata-rata posttest kelas kontrol sebesar 58,09 . hasil analisis diperoleh Sig. (2-tailed) $<0,05$ yakni $0,008<0,05$ yang artinya terdapat perbedaan yang signifikan.

\section{REFERENSI}

Arikunto, S. (2006). Prosedur Penelitian Suatu Pendekatan Praktik. Jakarta: Rineka Cipta.

Fisher, A. (2012). Berpikir Kritis Sebuah Pengantar. Jakarta: Erlangga.

Ressati, H. N. (2013). Efektivitas Metode Membelajaran Problem Solving terhadap kemampuan berpikir kritis siswa pada sub materi organ dan sistem organ dikelas XI sekolah menengah atas Negeri 3 Sintang.Skripsi tidak diterbbitkan. Sintang: STKIP Persada Khatulistiwa Sintang.

Sugiyono. (2013). Metode Penelitian Kuantitatif, Kualitatif dan $R \& D$. Bandung: Alfabeta. 
Pratama, dkk | Penerapan metode pembelajaran problem solving...

Sukardi. (2013). Metodologi Penelitian Pendidikan. Jakarta: Bumi Aksar 